\title{
PTPN11, SOS1, KRAS, and RAF1 gene analysis, and genotype-phenotype correlation in Korean patients with Noonan syndrome
}

\author{
Jung Min Ko · Jae-Min Kim · Gu-Hwan Kim • \\ Han-Wook Yoo
}

Received: 30 July 2008/ Accepted: 27 October 2008/Published online: 20 November 2008

(C) The Japan Society of Human Genetics and Springer 2008

\begin{abstract}
After 2006, germline mutations in the KRAS, SOS1, and RAF1 genes were reported to cause Noonan syndrome (NS), in addition to the PTPN11 gene, and now we can find the etiology of disease in approximately $60-70 \%$ of NS cases. The aim of this study was to assess the correlation between phenotype and genotype by molecular analysis of the PTPN11, SOS1, KRAS, and $R A F 1$ genes in 59 Korean patients with NS. We found disease-causing mutations in $30(50.8 \%)$ patients, which were located in the PTPN11 (27.1\%), SOS1 (16.9\%),
\end{abstract}

Electronic supplementary material The online version of this article (doi:10.1007/s10038-008-0343-6) contains supplementary material, which is available to authorized users.

J. M. Ko and J.-M. Kim contributed equally to this study.

J. M. Ko

Department of Pediatrics, Asan Medical Center,

University of Ulsan College of Medicine,

Seoul, South Korea

J.-M. Kim

Genome Research Center for Birth defects and Genetic Diseases, Asan Medical Center, University of Ulsan College of Medicine, Seoul, South Korea

\section{G.-H. Kim}

Medical Genetics Clinic and Laboratory,

Asan Medical Center, University of Ulsan

College of Medicine, Seoul, South Korea

H.-W. Yoo $(\bowtie)$

Department of Pediatrics, Medical Genetics Clinic

and Laboratory, Asan Medical Center,

University of Ulsan College of Medicine,

388-1, Pungnap-2dong, Songpa-gu,

Seoul 138-736, South Korea

e-mail: hwyoo@amc.seoul.kr
KRAS (1.7\%), and RAFl (5.1\%) genes. Three novel mutations (T59A in PTPN11, K170E in SOS1, S259T in $R A F 1)$ were identified. The patients with PTPN11 mutations showed higher prevalences of patent ductus arteriosus and thrombocytopenia. The patients with SOS1 mutations had a lower prevalence of delayed psychomotor development. All patients with RAF1 mutations had hypertrophic cardiomyopathy. Typical facial features and auxological parameters were, on statistical analysis, not significantly different between the groups. The molecular defects of NS are genetically heterogeneous and involve several genes other than PTPN11 related to the RASMAPK pathway.

Keywords Noonan syndrome - Genotype-phenotype correlation $\cdot$ PTPN11 $\cdot$ SOS1 $\cdot$ KRAS $\cdot$ RAF1

\section{Introduction}

Noonan syndrome (NS; OMIM 163950) is an autosomal dominant disorder with variable phenotype, characterized by short stature, congenital heart disease, and typical facial features (Noonan 1994). The main facial findings of NS are hypertelorism with down-slanting palpebral fissures, ptosis, and low-set posteriorly rotated ears. Other manifestations are webbed neck, chest wall deformity, mild mental retardation, cryptorchidism in males, feeding difficulties in infancy, bleeding diathesis, and lymphatic dysplasia (Allanson et al. 1985).

The genes that cause NS encode members of the RAS-MAPK pathway. Gain-of-function mutations in the PTPN11 gene, the first identified NS-associated gene (Tartaglia et al. 2001), account for 30-60\% of NS cases. In 2006, germline mutations in the KRAS gene were identified 
in five patients with NS (Schubbert et al. 2006), and germline mutations in the SOSI and RAFI genes were reported to cause NS in 2007. Therefore, deregulated RASMAPK signaling arising from PTPN11, SOS1, KRAS, and RAF1 mutations causes approximately $60-70 \%$ of NS cases (Pandit et al. 2007; Razzaque et al. 2007).

Attempts to find genotype-phenotype correlations have been performed by several authors (Bertola et al. 2006; Musante et al. 2003; Sarkozy et al. 2003; Zenker et al. 2004). Considering that approximately half of NS cases arise because of mutations in PTPN11, many studies have attempted to find a method for distinguishing the phenotype of PTPN11 NS cases from NS attributable to other causes. In some studies (Bertola et al. 2006; Tartaglia et al. 2002; Zenker et al. 2004), PS and hematological abnormalities were more prevalent in the NS group with PTPN11 gene mutations. On the other hand, Hypertrophic cardiomyopathy (HCM) was less often present in the NS group with PTPN11 gene mutations (Tartaglia et al. 2002). Recent reports have suggested that there might be an association between KRAS gene mutation and mental retardation (Zenker et al. 2007b), or between $R A F 1$ gene mutation and HCM (Pandit et al. 2007; Razzaque et al. 2007). Unusual ectodermal features, including facial keratosis pilaris and curly hair, and generally normal development and growth were associated with SOS1 gene mutations in another study (Tartaglia et al. 2007). In the present study, we conducted a mutation analysis on the PTPN11, SOS1, KRAS, and RAF1 genes in Korean patients with NS. In addition, we investigated genotype-phenotype correlations.

\section{Materials and methods}

\section{Clinical evaluation}

Fifty-nine unrelated Korean patients were diagnosed with NS by a single medical geneticist at the Asan Medical Center, Seoul, South Korea, between January 2000 and July 2007. This study was approved by institutional review boards, and written informed consent to our work was obtained from all subjects or from their parents. All patients had normal karyotypes. Inclusion criteria were based on the van der Burgt system (van der Burgt et al. 1994).

Electrocardiograms, simple chest radiographs, and echocardiograms were obtained from all patients for evaluation of cardiac anomalies. HCM was diagnosed when the left ventricular maximal end-diastolic wall thickness was $>2$ SD above the mean for a given age in children (Burch et al. 1993). Because objective evaluations, including the intelligence quotient, were not performed in all patients of this study, the diagnosis of delayed development or mental retardation was exclusively restricted to the patient who had required special education. IGF-1 and IGF binding protein-3 (IGFBP-3) levels were measured by immunoradiometric assays at diagnosis to evaluate the effects of these materials on growth. The levels of IGF-1 and IGFBP-3 are presented as standard deviation scores (SDS) with reference to normal Korean values (Lee and Kim 2007).

\section{Mutational analysis}

Genomic DNA was isolated from peripheral blood lymphocytes using the PUREGENE DNA isolation kit (Gentra, Minneapolis, MN). Four genes in the RASMAPK pathway associated with Noonan syndrome were analyzed for mutations; the genes were PTPN11, SOS1, $K R A S$, and $R A F 1$. PCR and sequence analysis explored all coding exons, and their intronic flanking regions, except in the case of RAF1. For the RAF1 gene, PCR and sequence analysis focused on exons 7,14 , and 17, which are major mutation sites (Pandit et al. 2007). Amplifications were performed over 30 cycles, and each cycle consisted of denaturation at $94^{\circ} \mathrm{C}$ for $30 \mathrm{~s}$, annealing at $55^{\circ} \mathrm{C}$ for $30 \mathrm{~s}$, and extension at $72^{\circ} \mathrm{C}$ for $45 \mathrm{~s}$. PCR was carried out in a reaction volume of $10 \mu \mathrm{l}$, containing $100 \mathrm{ng}$ of genomic DNA template, 10 pmol of each primer, $200 \mu \mathrm{M}$ of each dNTP, $2.5 \mathrm{mM} \mathrm{MgCl} 2,2.5 \mu \mathrm{l}$ of $10 \times$ buffer, and 1 unit of Taq DNA polymerase (Promega, Madison, WI). Primer sequences are available on request.

Subsequently, DNA sequencing reactions were performed using the same primer pairs, and the BigDye Terminator V3.1 Cycle Sequencing kit (Applied Biosystems, Foster City, CA) according to the manufacturer's instructions. Electrophoresis and analysis of sequencing reaction mixtures were achieved with an ABI3130xl Genetic Analyzer (Applied Biosystems).

To predict the functional impact of amino acid changes, we assessed novel sequence alterations by two in silico prediction algorithms, PolyPhen (Polymorphism Phenotyping) and SIFT (Sorting Intolerant from Tolerance), and performed molecular analyses in the patients' parents and 100 healthy controls additionally. On the PolyPhen program, a position-specific independent counts (PSIC) score of $>2.0$ indicates probably damaging to protein function, a score of 1.5-2.0 as possibly damaging, and a score of $<1.5$ as benign or unknown ( $\mathrm{Ng}$ and Henikoff 2003; Ramensky et al. 2002). 
Statistical analysis

Statistical analysis was carried out using the two-tailed Fischer's exact test and the Mann-Whitney $U$-test for between-group comparisons. $P$ values of $\leq 0.05$ were considered statistically significant.

\section{Results}

Study population

Fifty-nine unrelated Korean NS patients (41 boys and 18 girls) who met the inclusion criteria were enrolled in this study. Their ages at diagnosis ranged from 0.1 to 17.2 years (median 3.7 years). Three of 59 cases were familial $(5.1 \%)$, and transmission of NS was maternal in one patient and paternal in two patients.

\section{Spectrum of PTPN11, SOS1, KRAS, and RAF1} mutations (Table 1)

In 59 patients with NS, we identified mutations in 30 (50.8\%). Sixteen patients $(27.1 \%)$ had mutations in PTPN11, ten (16.9\%) in SOS1, one (1.7\%) in KRAS, and three $(5.1 \%)$ in $R A F 1$. Mutation analysis of PTPN11 showed a total of 13 different heterozygous missense variations, including one novel sequence alteration (T59A). We identified eight nonsynonymous sequence variations in the SOS1 gene, including a novel sequence alteration (K170E). These two novel alterations (T59A in PTPN11 and K170E in SOS1) were not found in 200 alleles of 100 healthy controls, and we confirmed that their parents did not harbor these alterations. As the results of analyses using the PolyPhen program, T59A and K170E were predicted to be possibly damaging to protein structure with PSIC scores of 1.530 and 1.609 , respectively. These two alterations also showed deleterious effects on the SIFT program. A KRAS gene mutation was detected in only one patient, and this mutation (V14I) has already been reported as a diseasecausing mutation.

Mutation analyses of the entire coding regions of the PTPN11, SOS1, and KRAS genes were negative in 32 patients. For these patients, we analyzed the sequences of exons 7, 14, and 17 of the RAFl gene, which have been reported as mutation hot-spot regions in two previous studies (Pandit et al. 2007; Razzaque et al. 2007). We identified two non-synonymous sequence alterations (S257L and S259T). S259T is considered to be a novel mutation, because this change was not found in the healthy controls, and a sequence change in the same site (S259F) has already been reported as a pathogenic change (Pandit et al. 2007). The PolyPhen and SIFT programs also showed
Table 1 PTPN11, SOS1, KRAS1, and RAF1 gene mutations identified in 59 patients with NS

\begin{tabular}{|c|c|c|c|c|}
\hline Exon & $\begin{array}{l}\text { Nucleotide } \\
\text { substitution }\end{array}$ & $\begin{array}{l}\text { Amino acid } \\
\text { substitution }\end{array}$ & Domain & $N(\%)$ \\
\hline \multicolumn{5}{|c|}{ PTPN11 $(N=16)$} \\
\hline 3 & c. $175 \mathrm{~A}>\mathrm{G}$ & $\mathrm{T}^{2} 9 \mathrm{~A}^{\mathrm{a}}$ & $\mathrm{N}-\mathrm{SH} 2$ & $1(6.3)$ \\
\hline 3 & c. $184 \mathrm{~T}>\mathrm{G}$ & Y62D & $\mathrm{N}-\mathrm{SH} 2$ & $1(6.3)$ \\
\hline 3 & c. $215 \mathrm{C}>\mathrm{G}$ & A72G & $\mathrm{N}-\mathrm{SH} 2$ & $2(12.5)$ \\
\hline 3 & c. $236 \mathrm{~A}>\mathrm{G}$ & Q79R & $\mathrm{N}-\mathrm{SH} 2$ & $2(12.5)$ \\
\hline 4 & c. $417 \mathrm{G}>\mathrm{C}$ & E139D & C-SH2 & $1(6.3)$ \\
\hline 8 & c. $854 \mathrm{~T}>\mathrm{C}$ & $\mathrm{F} 285 \mathrm{~S}$ & PTP & $1(6.3)$ \\
\hline 8 & c. $922 \mathrm{~A}>{ }^{\circ} \mathrm{G}$ & N308D & PTP & $1(6.3)$ \\
\hline 8 & c. $923 \mathrm{~A}>\mathrm{G}$ & N308S & PTP & $1(6.3)$ \\
\hline 12 & c. $1382 \mathrm{C}>\mathrm{T}$ & A461T & PTP & $2(12.5)$ \\
\hline 12 & c. $1391 \mathrm{G}>\mathrm{C}$ & G464A & PTP & $1(6.3)$ \\
\hline 12 & c. $1403 \mathrm{C}>\mathrm{T}$ & $\mathrm{T} 468 \mathrm{M}$ & РTP & $1(6.3)$ \\
\hline 13 & c. $1505 \mathrm{~A}>\mathrm{G}$ & S502L & PTP & $1(6.3)$ \\
\hline 13 & c. $1510 \mathrm{~A}>\mathrm{G}$ & M504V & PTP & $1(6.3)$ \\
\hline \multicolumn{5}{|c|}{$\operatorname{SOS1}(N=10)$} \\
\hline 4 & c. $508 \mathrm{~A}>\mathrm{G}$ & $\mathrm{K} 170 \mathrm{E}^{\mathrm{a}}$ & $\mathrm{HF}$ & $1(10)$ \\
\hline 6 & c. $797 \mathrm{C}>\mathrm{A}$ & $\mathrm{T} 266 \mathrm{~K}$ & $\mathrm{DH}$ & $1(10)$ \\
\hline 6 & c. $806 \mathrm{~T}>\mathrm{G}$ & M269R & $\mathrm{DH}$ & $2(20)$ \\
\hline 6 & c. $806 \mathrm{~T}>\mathrm{C}$ & M269T & $\mathrm{DH}$ & $1(10)$ \\
\hline 10 & c. $1297 \mathrm{G}>\mathrm{A}$ & $\mathrm{E} 433 \mathrm{~K}$ & $\mathrm{PH}$ & $1(10)$ \\
\hline 10 & c. $1322 \mathrm{G}>\mathrm{A}$ & $\mathrm{C} 441 \mathrm{Y}$ & $\mathrm{PH}$ & $1(10)$ \\
\hline 10 & c. $1642 \mathrm{~A}>\mathrm{C}$ & S548R & $\mathrm{HL}$ & $1(10)$ \\
\hline 10 & c. $1656 \mathrm{G}>\mathrm{C}$ & $\mathrm{R} 552 \mathrm{~S}$ & HL & $2(20)$ \\
\hline \multicolumn{5}{|c|}{$\operatorname{KRAS}(N=1)$} \\
\hline 2 & c. $40 \mathrm{G}>\mathrm{A}$ & V14I & P-loop & 1 \\
\hline \multicolumn{5}{|c|}{$R A F 1(N=3)$} \\
\hline 7 & c. $770 \mathrm{C}>\mathrm{T}$ & S257L & $\mathrm{CR} 2$ & $2(66.7)$ \\
\hline 7 & c. $775 \mathrm{~T}>\mathrm{A}$ & $\mathrm{S} 259 \mathrm{~T}^{\mathrm{a}}$ & $\mathrm{CR} 2$ & $1(33.3)$ \\
\hline
\end{tabular}

$N$-SH N-terminal of the $s r c$ homology domain, $C$-SH C-terminal of the src homology domain, PTP protein tyrosine phosphatase, $H F$ histone-like fold, $D H \mathrm{Dbl}$ homology domain, $P H$ pleckstrin homology domain, $H L$ helical linker, $C R$ conserved region

${ }^{\text {a }}$ Indicates a novel mutation

that S259T was predicted to affect protein structure and to be a mutation with a probably damaging effect, indicated by a PSIC score of 2.2.

Clinical findings in NS patients with PTPN11, SOS1, $K R A S$, and RAF1 mutations (Table 2)

\section{Patients with PTPN11 mutations}

In 16 patients with PTPN11 mutations, the median age at NS diagnosis was 2.5 years. The mean height and weight was $-2.75 \pm 1.52$ and $-2.21 \pm 1.34$ SDS. Also, mean IGF-1 and IGFBP-3 levels at diagnosis were $-2.07 \pm 1.72$ and $-0.04 \pm 0.85$ SDS, respectively. 
Table 2 Frequencies of characteristic NS findings grouped by genes in which mutations were detected

\begin{tabular}{|c|c|c|c|c|c|}
\hline \multirow[t]{2}{*}{ Clinical features } & \multicolumn{5}{|c|}{ N/Total (\%) of subjects } \\
\hline & $\begin{array}{l}\text { With PTPN11 } \\
\text { mutation }\end{array}$ & $\begin{array}{l}\text { With SOS1 } \\
\text { mutation }\end{array}$ & $\begin{array}{l}\text { With } K R A S \\
\text { mutation }\end{array}$ & $\begin{array}{l}\text { With } R A F 1 \\
\text { mutation }\end{array}$ & $\begin{array}{l}\text { Without } \\
\text { mutation }\end{array}$ \\
\hline Family history & $1 / 16(6)$ & $2 / 10(20)$ & - & $0 / 3$ & $0 / 29(0)$ \\
\hline \multicolumn{6}{|l|}{ Face } \\
\hline Typical features & $10 / 16(63)$ & $7 / 10(70)$ & + & $3 / 3$ & $16 / 29(55)$ \\
\hline \multicolumn{6}{|l|}{ Heart defect } \\
\hline PS & $8 / 16(50)$ & $5 / 10(50)$ & + & $0 / 3$ & $10 / 29(34)$ \\
\hline $\mathrm{HCM}$ & 3/16 (19) & 1/10 (10) & - & $3 / 3$ & $6 / 29(21)$ \\
\hline ASD & $5 / 16(31)$ & $3 / 10(30)$ & - & $1 / 3$ & $10 / 29(34)$ \\
\hline VSD & $1 / 16(6)$ & $3 / 10(30)$ & - & $1 / 3$ & $8 / 29(28)$ \\
\hline PDA & $5 / 16(31)^{\mathrm{a}}$ & $0 / 10(0)$ & - & $0 / 3$ & $2 / 29(7)$ \\
\hline Other & $1 / 16(6)$ & $0 / 10(0)$ & - & $0 / 3$ & $4 / 29(14)$ \\
\hline No defect & 2/16 (13) & $5 / 10(50)$ & - & $0 / 3$ & $6 / 29(21)$ \\
\hline \multicolumn{6}{|l|}{ Short stature } \\
\hline$<3$ rd percentile & $9 / 16(56)$ & $3 / 10(30)$ & - & $2 / 3$ & $16 / 29(55)$ \\
\hline$<10$ th percentile & $11 / 16(69)$ & $6 / 10(60)$ & - & $2 / 3$ & $21 / 29(72)$ \\
\hline Thorax deformity & $4 / 16(25)$ & $4 / 10(40)$ & - & $0 / 3$ & $6 / 29(21)$ \\
\hline $\begin{array}{l}\text { Delayed development } \\
\text { or mental retardation }\end{array}$ & $4 / 15(27)$ & $0 / 10(0)^{\mathrm{a}}$ & + & $2 / 3$ & $13 / 28(46)$ \\
\hline Cryptorchidism & $3 / 11(27)$ & $3 / 6(50)$ & - & $1 / 2$ & $12 / 21(57)$ \\
\hline Neonatal lymphedema & 2/16 (13) & $3 / 10(30)$ & - & $0 / 3$ & $2 / 29(7)$ \\
\hline Sensorineural hearing loss & 3/16 (19) & $0 / 10(0)$ & - & $0 / 3$ & $2 / 29(7)$ \\
\hline Thrombocytopenia & $3 / 16(19)^{\mathrm{a}}$ & $0 / 10(0)$ & - & $0 / 3$ & $0 / 29(0)$ \\
\hline
\end{tabular}

$P S$ pulmonic stenosis, $H C M$ hypertrophic cardiomyopathy, $A S D$ atrial septal defect, $V S D$ ventricular septal defect, $P D A$ patent ductus arteriosus

${ }^{\text {a }} P<0.05$ compared with patients who belonged to the other four groups

Fourteen $(87.5 \%)$ patients had congenital heart diseases, of which PS was most frequently observed (50.0\%). Patent ductus arteriosus (PDA) and HCM were observed in five $(31.3 \%)$ and three $(18.8 \%)$ patients, respectively. Two or more heart defects were present in 8 of 14 patients with heart diseases.

In comparison to the patients with other gene mutations plus those with no discernible mutations, significantly higher prevalences of PDA $(31.3 \%, P=$ $0.018)$ and thrombocytopenia $(18.8 \%, P=0.017)$ were observed in patients with PTPN11 mutations. The mean IGF-1 SDS value of this group seemed to be lower, with marginal significance $(P=0.065)$, though the mean IGFBP-3 SDS was not different. The patients with PTPN11 mutations did not show a higher prevalence of PS statistically.

\section{Patients with SOS1 mutations}

In ten patients with SOS1 mutations, the mean height and weight were $-2.21 \pm 1.34$ and $-1.75 \pm 0.86$ SDS. The median age at NS diagnosis was 10.3 years, and mean
IGF-1 and IGFBP-3 levels at diagnosis were $-1.60 \pm 1.01$ and $0.70 \pm 1.32$ SDS.

Five patients $(50 \%)$ had congenital heart diseases, of which PS was most frequently observed (in all five patients). Two or more heart defects were combined in all patients who had heart diseases, and the other five (50\%) patients showed structurally normal hearts. No subject showed delayed mental development requiring special education, and this prevalence was significantly lower in these patients than in subjects with the other genotypes $(P=0.011)$. Classical ectodermal features, including facial keratosis pilaris and curly hair, were not observed in patients with SOSI mutations.

\section{Patient with KRAS mutation}

Only one boy had a KRAS gene mutation (V14I). He was diagnosed with NS at the age of 3.6 years, and his height and weight were -0.14 and -0.05 SDS, respectively. He exhibited the typical facial features with strabismus, showed isolated PS, and had delayed mental development requiring special education. 


\section{Patients with RAF1 mutations}

Three patients had RAF1 mutations, and the median age at diagnosis was 2.25 years. The median height and weight were -2.92 and -1.29 SDS, and the median IGF-1 and IGFBP-3 levels were -3.00 and 0.45 SDS, respectively. All three patients with $R A F 1$ mutations had the same type of heart defect (HCM), and HCM was more frequently observed in this group compared to the patients without RAFl mutations $(P=0.009)$. However, we could not associate the various phenotypic characteristics with genotype-specific findings.

Patients without PTPN11, SOS1, KRAS, or RAF1 mutations

Patients in this group were diagnosed at the median age of 4.8 years and showed similar height SDS, weight SDS, and IGFBP-3 values to those of the patients with any NS-relevant mutation. However, the mean IGF-1 SDS value $(-0.57 \pm 0.65)$ of this group was higher than that of the other groups with any discernable mutations $(P=0.003)$. The prevalence of cardiac anomalies other than PDA, thorax deformities, and delayed mental development did not differ from the other groups.

\section{Discussion}

Spectrum of PTPN11, SOS1, KRAS, and $R A F 1$ mutations

In total, we found mutations in $30(50.8 \%)$ of patients as the results of analyses in four genes involved in the RASMAPK pathway. This is a relatively lower frequency than that of previously reported studies, especially in the case of the PTPN11 gene (Jongmans et al. 2004; Tartaglia et al. 2002; Zenker et al. 2004). Sixteen patients (27.1\%) had PTPN11 mutations. This proportion is comparable to those published in some reports (Musante et al. 2003; Zenker et al. 2007b), but is lower than in other studies (Tartaglia et al. 2002; Zenker et al. 2004). The finding that a relatively high percentage of patients undoubtedly fitting NS criteria did not carry a mutation in PTPN11 confirms previous studies indicating that NS is a genetically heterogeneous syndrome.

Most (93.8\%) of PTPN11 mutations in our study were localized in exons $3,8,12$, or 13 , which are thought to be hot-spot regions (Musante et al. 2003; Sarkozy et al. 2003; Tartaglia et al. 2002; Zenker et al. 2004). Also, we identified one novel PTPN11 mutation (T59A) in exon 3. N308D, which is known to be the most prevalent mutation (Jongmans et al. 2004), was found in only one of our patients. To our knowledge, our study is the second report of molecular analyses in the patients with Korean NS; however, the previous study reported that four of seven PTPN11 mutations were N308D (Lee et al. 2007). This discrepancy might be caused by two reasons. First, the cohort number of the previous study was very small and, therefore, genotypes and phenotypes could not be analyzed statistically. Second, the previous study has a limitation that they were performed in just one institute, like in our study.

To date, at least three studies have established that mutations in the SOS1 gene are the second most prevalent cause of NS (Roberts et al. 2007; Tartaglia et al. 2007; Zenker et al. 2007a). Mutation detection rates were 17$28 \%$ amongst clinically well-characterized patients who lacked mutations in the PTPN11 gene. The SOS1 mutation detection rate (16.9\%) and distribution of the SOS1 mutations identified in our study correspond with the results of previous works. Most SOS1 mutations detected were localized in exons 6 and 10, and one novel mutation (K170E) in exon 4 was detected. D169-residue was suggested to be an important site for stabilizing the inactive conformation of SOS1 protein. Mutations of D169- and surrounding residues led to dysregulation of Ras binding and activation in one previous study (Sondermann et al. 2005). It might be a probable mechanism of action of K170E mutation.

Sequence alterations in KRAS accounted for approximately $2.1 \%$ of NS cases in previous studies (Zenker et al. 2007b). We found only one (1.7\%) patient with a KRAS mutation (V14I) in 59 patients with NS. This mutation has been reported previously, and a patient with the V14I substitution had a milder clinical phenotype than a patient with the T58I mutation (Schubbert et al. 2006).

All pathogenic mutations previously reported in $R A F 1$ were located in only three exons (exons $7,14,17$ ), and these exons were thought to be the hot-spot regions. Mutations located in the CR2 domain seemed to be especially associated with HCM. Several lines of evidence have implicated RAS-MAPK signaling in cardiac hypertrophy (Bueno et al. 2000; Muslin 2005), and these could explain why the specific $R A F 1$ mutations that increase ERK activation result in cardiac hypertrophy. Among the three exons that we examined, $R A F 1$ mutations in our study were identified in exon 7 of the CR2 domain, and all RAF1 mutation-positive patients showed HCM.

\section{Genotype-phenotype correlation}

Attempts to define genotype-phenotype correlations have been undertaken by several authors (Bertola et al. 2006; Musante et al. 2003; Sarkozy et al. 2003; Sznajer et al. 2007; Tartaglia et al. 2002; Zenker et al. 2004), but definite 
conclusions have not been reached. In most previous studies, PS was more prevalent in the group with PTPN11 gene mutations than in other groups (Sznajer et al. 2007; Tartaglia et al. 2002; Zenker et al. 2004). In one previous study of Sarkozy et al. (2003), however, no difference between PTPN11-positive and PTPNI1-negative patients in the prevalence of this heart defect was found. We did not find a strong association between PS and PTPN11 gene mutations, but PDA was found more frequently in the PTPN11 mutation-positive group than in other patients. Although only one patient had isolated PDA (PS and HCM was combined with PDA in each of two patients), the total prevalence of PDA in our patients was $13.5 \%$, a higher proportion than in previous reports (Allanson 1987; Sharland et al. 1992; Sznajer et al. 2007). Recently reported work has suggested an association between RAFl gene mutations and HCM (Pandit et al. 2007; Razzaque et al. 2007), and the result of the present study also supports this suggestion. A beneficial effect of $\mathrm{GH}$ has already been reported in NS patients (Kirk et al. 2001; Limal et al. 2006), and GH administration is an established treatment for NS (Kelnar 2003; Raaijmakers et al. 2008). Because the cost of GH therapy is not covered by public medical insurance in Korea, only eight of our patients were treated with $\mathrm{GH}$, and we therefore could not assess differences in GH efficacy between genotype groups. However, it is well known that GH therapy affects cardiac muscle mass (Isgaard 2004). GH therapy in NS patients with HCM might be dangerous, because such cases are at relatively high risk for the development of progressive ventricular hypertrophy. Therefore, before treating NS patients with GH, it would be important to screen for mutations in the RAFl gene and to engage in careful cardiac structure monitoring.

The mean baseline IGF-1 and IGFBP-3 concentrations were -1.46 and $0.10 \mathrm{SDS}$ in our patients, values that are comparable to those of Limal et al. (2006). Because PTPN11, SOS1, and RAF1 mutations induce abnormalities in many growth factor-signaling pathways, we suggest that an impaired production of IGF-1 and other growth factors in NS may lead to reduced biological activities of these factors. A partial resistance to GH in NS is well known, especially in PTPN11 mutation-positive patients (Binder et al. 2005; Limal et al. 2006). In addition, the patients without any mutation had a higher mean IGF-1 concentration than the patients with any of the mutations, and those with PTPN11 mutations showed a lower value of IGF-1 SDS with marginal significance in this study. This finding suggests that another causative gene of NS might exist, which is independent of growth factor-signaling pathways, including the RAS-MAPK pathway.

Up to one-third of patients with NS show mental retardation, although in most cases it is mild (Allanson 1987). Interestingly, it has been suggested that a most important discriminating feature is the absence of significant mental retardation in patients with SOS1 mutations (Tartaglia et al. 2007; Zenker et al. 2007a). However, the prevalence of mental retardation seemed to be higher in patients with KRAS mutations (Schubbert et al. 2006; Zenker et al. 2007b). The prevalence of delayed mental development requiring special education was $33.9 \%$ in our study. Among our patients, no subject with an SOS1 mutation showed delayed mental development, and, notably, the patient with the KRAS mutation showed delayed mental development requiring special education.

Hematological findings in NS are well-described, and include abnormal platelet count and function and coagulation factor deficiencies. Up to $55 \%$ of cases have a mildto-moderate bleeding tendency, and severe hemorrhage occurs in $3 \%$ of cases (van der Burgt 2007). The T73I mutation in the PTPN11 gene is associated with a predisposition to myeloproliferative disorder, which most often resolves spontaneously (Tartaglia et al. 2003). There was no myeloproliferative disorder in our patients, and no T73I mutation in the PTPN11 gene was seen in our study. Thrombocytopenia was only observed in the patients with PTPN11 mutations, and this finding is consistent with previous studies (Bertola et al. 2006; Zenker et al. 2004).

There are some limitations to our study. First, this study was performed in one institute, which may have selection bias. Second, not all exons of RAFl gene were analyzed and there may be mutations on the other exons. Third, the wide distribution of patients' age might affect the phenotypes. Lastly, we did not perform any functional study for three putative novel mutations. Further studies including Korean NS patients, with their molecular analyses, should help to allow a more accurate genotype-phenotype correlation and to provide information in genetic counseling.

In conclusion, great progress in the detection and analysis of NS-causative genes has been achieved in recent years, but NS is still a challenging disorder. Our study illustrates the wide spectrum of developmental anomalies that result from deregulation of the RAS-MAPK signaling pathway and offers suggestions for genotype-phenotype correlations.

Acknowledgments We express our gratitude to the patients and their family members for their participation in this study. This study was supported by grant no. 01-PJ10-PG6-01GN15-0001 from the Korean Ministry of Health and Welfare.

\section{References}

Allanson JE (1987) Noonan syndrome. J Med Genet 24:9-13 Allanson JE, Hall JG, Hughes HE, Preus M, Witt RD (1985) Noonan syndrome: the changing phenotype. Am J Med Genet 21:507514 
Bertola DR, Pereira AC, Albano LM, De Oliveira PS, Kim CA, Krieger JE (2006) PTPN11 gene analysis in 74 Brazilian patients with Noonan syndrome or Noonan-like phenotype. Genet Test 10:186-191

Binder G, Neuer K, Ranke MB, Wittekindt NE (2005) PTPN11 mutations are associated with mild growth hormone resistance in individuals with Noonan syndrome. J Clin Endocrinol Metab 90:5377-5381

Bueno OF, De Windt LJ, Tymitz KM, Witt SA, Kimball TR, Klevitsky R, Hewett TE, Jones SP, Lefer DJ, Peng CF, Kitsis RN, Molkentin JD (2000) The MEK1-ERK1/2 signaling pathway promotes compensated cardiac hypertrophy in transgenic mice. Embo J 19:6341-6350

Burch M, Sharland M, Shinebourne E, Smith G, Patton M, McKenna W (1993) Cardiologic abnormalities in Noonan syndrome: phenotypic diagnosis and echocardiographic assessment of 118 patients. J Am Coll Cardiol 22:1189-1192

Isgaard J (2004) Cardiovascular disease and risk factors: the role of growth hormone. Horm Res 62(Suppl 4):31-38

Jongmans M, Otten B, Noordam K, van der Burgt I (2004) Genetics and variation in phenotype in Noonan syndrome. Horm Res 62(Suppl 3):56-59

Kelnar CJ (2003) The role of somatotropin therapy in children with Noonan syndrome. Treat Endocrinol 2:165-172

Kirk JM, Betts PR, Butler GE, Donaldson MD, Dunger DB, Johnston DI, Kelnar CJ, Price DA, Wilton P, Group tU (2001) Short stature in Noonan syndrome: response to growth hormone therapy. Arch Dis Child 84:440-443

Lee ST, Ki CS, Lee HJ (2007) Mutation analysis of the genes involved in the Ras-mitogen-activated protein kinase (MAPK) pathway in Korean patients with Noonan syndrome. Clin Genet 72:150-155

Lee JK, Kim CH (2007) Standard growth chart for Korean children and adolescent. Kwangmoon, Seoul, pp 4-13

Limal JM, Parfait B, Cabrol S, Bonnet D, Leheup B, Lyonnet S, Vidaud M, Le Bouc Y (2006) Noonan syndrome: relationships between genotype, growth, and growth factors. J Clin Endocrinol Metab 91:300-306

Musante L, Kehl HG, Majewski F, Meinecke P, Schweiger S, Gillessen-Kaesbach G, Wieczorek D, Hinkel GK, Tinschert S, Hoeltzenbein M, Ropers HH, Kalscheuer VM (2003) Spectrum of mutations in PTPN11 and genotype-phenotype correlation in 96 patients with Noonan syndrome and five patients with cardiofacio-cutaneous syndrome. Eur J Hum Genet 11:201-206

Muslin AJ (2005) Role of raf proteins in cardiac hypertrophy and cardiomyocyte survival. Trends Cardiovasc Med 15:225-229

Ng PC, Henikoff S (2003) SIFT: predicting amino acid changes that affect protein function. Nucleic Acids Res 31:3812-3814

Noonan JA (1994) Noonan syndrome. An update and review for the primary pediatrician. Clin Pediatr (Phila) 33:548-555

Pandit B, Sarkozy A, Pennacchio LA, Carta C, Oishi K, Martinelli S, Pogna EA, Schackwitz W, Ustaszewska A, Landstrom A, Bos JM, Ommen SR, Esposito G, Lepri F, Faul C, Mundel P, Lopez Siguero JP, Tenconi R, Selicorni A, Rossi C, Mazzanti L, Torrente I, Marino B, Digilio MC, Zampino G, Ackerman MJ, Dallapiccola B, Tartaglia M, Gelb BD, Razzaque MA, Nishizawa T, Komoike Y, Yagi H, Furutani M, Amo R, Kamisago M, Momma K, Katayama H, Nakagawa M, Fujiwara Y, Matsushima M, Mizuno K, Tokuyama M, Hirota H, Muneuchi J, Higashinakagawa T, Matsuoka R (2007) Gain-of-function RAF1 mutations cause Noonan and LEOPARD syndromes with hypertrophic cardiomyopathy. Nat Genet 39:1007-1012

Raaijmakers R, Noordam C, Karagiannis G, Gregory JW, Hertel NT, Sipila I, Otten BJ (2008) Response to growth hormone treatment and final height in Noonan syndrome in a large cohort of patients in the KIGS database. J Pediatr Endocrinol Metab 21:267-273
Ramensky V, Bork P, Sunyaev S (2002) Human non-synonymous SNPs: server and survey. Nucleic Acids Res 30:3894-3900

Razzaque MA, Nishizawa T, Komoike Y, Yagi H, Furutani M, Amo R, Kamisago M, Momma K, Katayama H, Nakagawa M, Fujiwara Y, Matsushima M, Mizuno K, Tokuyama M, Hirota H, Muneuchi J, Higashinakagawa T, Matsuoka R (2007) Germline gain-of-function mutations in RAF1 cause Noonan syndrome. Nat Genet 39:1013-1017

Roberts AE, Araki T, Swanson KD, Montgomery KT, Schiripo TA, Joshi VA, Li L, Yassin Y, Tamburino AM, Neel BG, Kucherlapati RS (2007) Germline gain-of-function mutations in SOS1 cause Noonan syndrome. Nat Genet 39:70-74

Sarkozy A, Conti E, Seripa D, Digilio MC, Grifone N, Tandoi C, Fazio VM, Di Ciommo V, Marino B, Pizzuti A, Dallapiccola B (2003) Correlation between PTPN11 gene mutations and congenital heart defects in Noonan and LEOPARD syndromes. $\mathrm{J}$ Med Genet 40:704-708

Schubbert S, Zenker M, Rowe SL, Boll S, Klein C, Bollag G, van der Burgt I, Musante L, Kalscheuer V, Wehner LE, Nguyen H, West B, Zhang KY, Sistermans E, Rauch A, Niemeyer CM, Shannon K, Kratz CP (2006) Germline KRAS mutations cause Noonan syndrome. Nat Genet 38:331-336

Sharland M, Burch M, McKenna WM, Paton MA (1992) A clinical study of Noonan syndrome. Arch Dis Child 67:178-183

Sondermann H, Nagar B, Bar-Sagi D, Kuriyan J (2005) Computational docking and solution X-ray scattering predict a membrane-interacting role for the histone domain of the Ras activator son of sevenless. Proc Natl Acad Sci USA 102:1663216637

Sznajer Y, Keren B, Baumann C, Pereira S, Alberti C, Elion J, Cave $\mathrm{H}$, Verloes A (2007) The spectrum of cardiac anomalies in Noonan syndrome as a result of mutations in the PTPN11 gene. Pediatrics 119:e1325-e1331

Tartaglia M, Kalidas K, Shaw A, Song X, Musat DL, van der Burgt I, Brunner HG, Bertola DR, Crosby A, Ion A, Kucherlapati RS, Jeffery S, Patton MA, Gelb BD (2002) PTPN11 mutations in Noonan syndrome: molecular spectrum, genotype-phenotype correlation, and phenotypic heterogeneity. Am J Hum Genet 70:1555-1563

Tartaglia M, Mehler EL, Goldberg R, Zampino G, Brunner HG, Kremer H, van der Burgt I, Crosby AH, Ion A, Jeffery S, Kalidas K, Patton MA, Kucherlapati RS, Gelb BD (2001) Mutations in PTPN11, encoding the protein tyrosine phosphatase SHP-2, cause Noonan syndrome. Nat Genet 29:465468

Tartaglia M, Niemeyer CM, Fragale A, Song X, Buechner J, Jung A, Hahlen K, Hasle H, Licht JD, Gelb BD (2003) Somatic mutations in PTPN11 in juvenile myelomonocytic leukemia, myelodysplastic syndromes and acute myeloid leukemia. Nat Genet 34:148-150

Tartaglia M, Pennacchio LA, Zhao C, Yadav KK, Fodale V, Sarkozy A, Pandit B, Oishi K, Martinelli S, Schackwitz W, Ustaszewska A, Martin J, Bristow J, Carta C, Lepri F, Neri C, Vasta I, Gibson K, Curry CJ, Siguero JP, Digilio MC, Zampino G, Dallapiccola B, Bar-Sagi D, Gelb BD (2007) Gain-of-function SOS1 mutations cause a distinctive form of Noonan syndrome. Nat Genet 39:75-79

van der Burgt I (2007) Noonan syndrome. Orphanet J Rare Dis 2:4 van der Burgt I, Berends E, Lommen E, van Beersum S, Hamel B, Mariman E (1994) Clinical and molecular studies in a large Dutch family with Noonan syndrome. Am J Med Genet 53:187191

Zenker M, Buheitel G, Rauch R, Koenig R, Bosse K, Kress W, Tietze HU, Doerr HG, Hofbeck M, Singer H, Reis A, Rauch A (2004) Genotype-phenotype correlations in Noonan syndrome. J Pediatr 144:368-374 
Zenker M, Horn D, Wieczorek D, Allanson J, Pauli S, van der Burgt I, Doerr H-G, Gaspar H, Hofbeck M, Gillessen-Kaesbach G, Koch A, Meinecke P, Mundlos S, Nowka A, Rauch A, Reif S, von Schnakenburg C, Seidel H, Wehner L-E, Zweier C, Bauhuber S, Matejas V, Kratz CP, Thomas C, Kutsche K (2007a) SOS1 is the second most common Noonan gene but plays no major role in cardio-facio-cutaneous syndrome. J Med Genet 44:651-656
Zenker M, Lehmann K, Schulz AL, Barth H, Hansmann D, Koenig R, Korinthenberg R, Kreiss-Nachtsheim M, Meinecke P, Morlot S, Mundlos S, Quante AS, Raskin S, Schnabel D, Wehner L-E, Kratz CP, Horn D, Kutsche K (2007b) Expansion of the genotypic and phenotypic spectrum in patients with KRAS germline mutations. J Med Genet 44:131-135 